\title{
GEOLOGICAL AND GEOMECHANICAL PROPERTIES OF SOME CARBONATE MARBLES AND BASALT STONE FROM MOROCCO
}

\author{
1'Veysel ZEDEF, ${ }^{2}$ Kerim KOÇAK, ${ }^{3}$ Najib Mohamed ZAGHLOUL, ${ }^{4}$ Adnan DÖYEN, ${ }^{5} A l i$ Riza SÖĞÜT, \\ ${ }^{6}$ Hakan ÖZŞEN, ${ }^{7 B i l g e h a n ~ K E K E C ̧, ~}{ }^{8}$ Ali ARAS, ${ }^{9}$ Kemal DOĞAN, ${ }^{10}$ Tevfik AĞAÇAYAK \\ 1,6,7,8,9,10Selcuk University, Department of Mining Engineering, Campus, Selcuklu, Konya, TURKEY \\ 2,4,5Selcuk University, Department of Geology, Campus, Selcuklu, Konya, TURKEY \\ ${ }^{3}$ Abdelmalek Essaadi University, Department of Earth Sciences, Tanger, MOROCCO \\ 1 vzedef@selcuk.edu.tr, 2kkocak@selcuk.edu.tr, 3zaghloul@geologist.com, 4adoyen@selcuk.edu.tr, \\ 5arsogut@selcuk.edu.tr, 6hozsen@selcuk.edu.tr, 7kekec@selcuk.edu.tr, 8aliaras@selcuk.edu.tr, \\ 9kdogan@selcuk.edu.tr, 10tevfik@selcuk.edu.tr
}

(Geliş/Received: 02.03.2017; Kabul/Accepted in Revised Form: 28.03.2017 )

\begin{abstract}
The natural rocks used today as well as in the history for a variety of purposes were a subject of different alteration, weathering and deterioration conditions. These conditions are strictly controlled by environment and nature of rock varieties (marble and stone). This study is a first approach to understand the relation between some geological features and behavior against salt $\left(\mathrm{Na}_{2} \mathrm{SO}_{4}\right)$ decay of Moroccan marbles and stones. For this purpose, widely used four dolomitic limestones, two crystalline limestones, one limestone and one basalt sample (total 8) were chosen from Morocco. Extra attention paid to choose locations being a representative of all Moroccan country. The carbonate samples (limestone and dolomite) consist of mainly dolomite and calcite with micritic and sparitic cement. The sole, non-carbonaceous sample is basalt of Khenifra containing mainly plagioclase and pyroxene. In general, both bulk-dry and powder density values of the studied rock samples are homogeneous. The limestone of Bir Jdid has the highest (10.81\%) effective porosity and dry weight loss value $(4.61 \%)$. The loss on ignition value of the Khenifra basalt has the low est value with $1.26 \%$. The loss on ignition values are also relatively uniform. The obtained data indicate that outdoor uses (especially in coastal areas) of limestones of Bir Jdid and dolomitic limestones of Taza are more risky than the others.
\end{abstract}

Key Words: Geomechanical and geological features, Marbles, Stones, Dry-weight loss, Morocco

\section{Fas'ın Bazı Karbonat Mermerleri ve Bazalt Taşlarının Jeolojik ve Jeomekanik Özellikleri}

ÖZ: Hem geçmiş dönemlerde hem de günümüzde çok çeşitli amaçlar için kullanılan doğal taşlar farklı ayrışma, dağılma ve bozunmaya uğramakta dırlar. Bu şartlar çevre ve kayacın türüne (mermer ve taş) sıkı sıkıya bağlıdır. Bu çalışma Fas mermerleri ve taşlarını tuza ( $\left.\mathrm{Na}_{2} \mathrm{SO}_{4}\right)$ karşı dayanımlarını ve bazı jeolojik özelliklerini anlamak için yapılan ilk çalışmadır. Bunun için Fas'tan getirilen çok kullanılan 4 dolomit, 2 kristalize kireçtaşı, 1 kireçtaşı ve bir bazalt (toplam 8 adet) örneği seçilmiştir. Örnekler mümkün mertebe Fas'ın değişik yerlerinden seçilmiştir. Karbonat kayaçları (kireçtaşı ve dolomit) temel olarak dolomit ve kalsit minerallerinden müteşekkil olup çimento mikrit ve sparittir. Karbonatsız tek kayaç olan Khenifra bazaltı esasen plajiyoklas ve piroksen içerir. Genel olarak örneklerin kuru ve öğütülmüş ağırlıkları birbirlerine benzer. Bir Jdid kireçtaşları en yüksek etkili porozite (\% 10.81) ve kuru ağırlık kaybına (\%4.61) sahiptir. En düşük ateş zayiatı Khenifra bazaltlarındadır (\%1.26). Ateş zayiatları genel olarak homojendir. Eldeki veriler Bir Jdid kireçtaşları ve Taza dolomitik kireçtaşlarının dışarda (özellikle sahil bölgelerinde) kullanımlarının diğerlerine göre daha riskli olduğuna işaret etmektedir. 
Anahtar Kelimeler: Jeomekanik ve jeolojik özellikler, Mermerler, Taşlar,Kkuru ağırlık kaybı, Fas

\section{INTRODUCTION}

The natural rocks throughout the world have been extensively used for various purposes, for example as building stones, ornamental stones and sculptures. These types of the usage of the natural rocks throughout the history can be seen in places of worships (mosques, churches, synagogues and temples of various civilizations), palaces, fountains, caravanserais and many more. Today, the rocks have been used as building stones, artw orks and ornamental stones as in the past. These rocks lose their original look since they affected by natural and artificial reasons. The rocks used in several applications mentioned above, have to be preserved for not only their aesthetic values but for future generations as an important proof from past. To preserve them, enough information has to be provided on rocks' geological, mechanical and chemical properties.

There are many factors that affect weathering-alteration-deterioration conditions of the natural rocks. The natural structure (mineralogical-chemical compositions, petrographic properties and physical resistance) of the rocks, environmental conditions and negative corrosive effect of the salt are the most important of them. Processes that cause alteration- weathering of the rocks have been investigated for long time. The first published data (or to our knowledge) for alteration of rocks belong the year 1895 (Yu and Oguchi, 2010). Important agents affecting the stability of the rocks have been described in detail by Shaffer (1932) and later on by Winkler (1966). These two studies are the milestones of this subject and still find places in reference lists. Extensive works have been published in the last two decades. The factors causing the alteration-weathering and deterioration of the rocks can roughly be divided into three, namely chemical, physical and biological processes (e.g., Blows et al., 2003). In practice almost all type of weathering-alteration processes (chemical, physical and biological) progress altogether within and/or surface of the rocks. Combination of these processes significantly enhances the intensity of decay when compared with the physical or biological agents acting along (e.g., Papida et al., 2000).

Chemical processes start with separation of fresh rocks. During this separation some ions and molecules became free for formation of new minerals (Eden, 1990). Lal Gauri and Bandyopathyay (1999) provided very detailed reaction pathways for especially carbonate rocks. Circulating $\mathrm{SO}_{2}, \mathrm{NO}_{x}$ and $\mathrm{CO}_{x}$ gases within atmosphere and hydrosphere could react with $\mathrm{K}^{+}, \mathrm{Ca}^{+}, \mathrm{Na}^{+}, \mathrm{Mg}^{+}, \mathrm{Fe}^{+}$(and so on) found within the rocks and their surface (if any) to form salts. When water phases evacuated from the environment salts start to crystallize to give rise pressure (by volume increase) on the rocks. This pressure causes disintegration of the rocks. The gases mentioned above are directly related to environmental pollution, thus the alteration of rocks is also associated to environmental pollutions. The types of rocks are also an important part of alteration degree and speed (Zedef et al., 2007).

A variety of Moroccan carbonate marbles and stones have been used for several purposes at present as well as in the history. Although there have been many carbonate marble and other building stone sources in Morocco, many of them are under operate, there have been no study (at least to our knowledge) on their physical, chemical, geological and geomechanical properties. This study is a first approach of a research aimed at understanding the nature of the stone materials produced by complex geological processes of Morocco (Because of this, we also displayed a very brief explanation of the geological background of Morocco).

More than $70 \%$ of Morocco is covered by mountains which have been shaped by continental collision. In the geological point of view, Morocco can essentially divided into five parts (also known as tectonic units) from South to North (Stets and Wurster, 1982; Crevello, 1991; Ledo et al., 2011): (I) The Anti-Atlas mountains lies in the South of the country and they can be high up to $2500 \mathrm{~m}$. In this unit, Paleozoic aged formations and Hercinien Orogenesis is dominant, but the rocks were deformed very little. The Anti-Atlas mountains is a part of the northwestern part of African Craton, (II) The High Atlas Mountains raise in the central which has $700 \mathrm{~km}$ long from East to West and can be reach up to $4000 \mathrm{~m}$ high. This unit has more tectonic deformation when compared to the Anti -Atlases. The unit was formed 
during Paleozoic and covered unconformably by slightly folded Mesozoic and Cenozoic formations. (III) The middle Atlas Mountains found in the North of the High Atlas and they include extremely thick Mesozoic aged sedimentary rocks, (IV) The Rif Mountains are located at the far most north of the country along with Atlantic Ocean and Mediterranean costs. Intensively deformed Mesozoic and Cenozoic aged rocks are the main features of the Rif Mountains, and (V) Moroccan Mesata includes plateaus and plains of recent alluviums. The Mesata covers a large area along the cost of Atlantic Ocean, but not considered as tectonic unit (Figure 1). The investigated carbonate marbles and stones are a part of these rock units.

\section{METHODOLOGY}

This investigation was limited to 8 locations in which carbonate marbles and basalt stones outcropped (Figure 1). All these rocks have indoor and outdoor applica tions allover Morocco since they have well developed joint system. Petrographic investigations were carried out on thin sections by using polarizing microscope. The polarizing microscope, in turn, and X-Ray diffractometer (XRD) were used for mineralogical identifications. The XRD analyses were done at the laboratories of Gebze Technology Institute, Izmit, Turkey. All other analyses were undertaken at Selcuk University, Konya, Turkey. The geomechanical tests were applied at least three samples of the rocks studied. The loss on ignition (LOI) was measured on 250 mesh pow dered samples at $1000^{\circ} \mathrm{C}$.

The quantification of salt weathering of the samples was measured by assessing the dry weight loss (DWL) of the rocks. There have been many laboratory test proposed for DWL determinations. The most used tests are the American standard test ASTM (C-88, C-128), the Germany standard test DIN (52111) and the Spanish standard test UNE-EN (12370). All these test have three stages: immersion (total), drying and cooling. We followed the Spanish standard test for DWL assessments (except the dimension of the samples since we had some difficulty to provide thick samples, nevertheless the test allow us to compare the rocks against salt effect). In this test $14 \% \mathrm{Na}_{2} \mathrm{SO}_{4}$ solution was used. In the immersion stage, clean and dry rock samples were introduced into a container and covered with the solution at $20^{\circ} \mathrm{C}$ for 4 $\mathrm{h}$. In the drying stage, the samples were taken out of the container and settled into the heating cabinet at $60{ }^{\circ} \mathrm{C}$ for $16 \mathrm{~h}$. The duration of this cycle is $24 \mathrm{~h}$ and the similar procedure was repeated for 15 days (total 15 cycles). The solution was changed every five cycles as the samples lose weight. After 15 days, the tested samples were cleaned with pure water to eliminate salt. The samples were then dried until a constant weight realized. The dry weight loss (DWL \%) was calculated at the end of this stage.

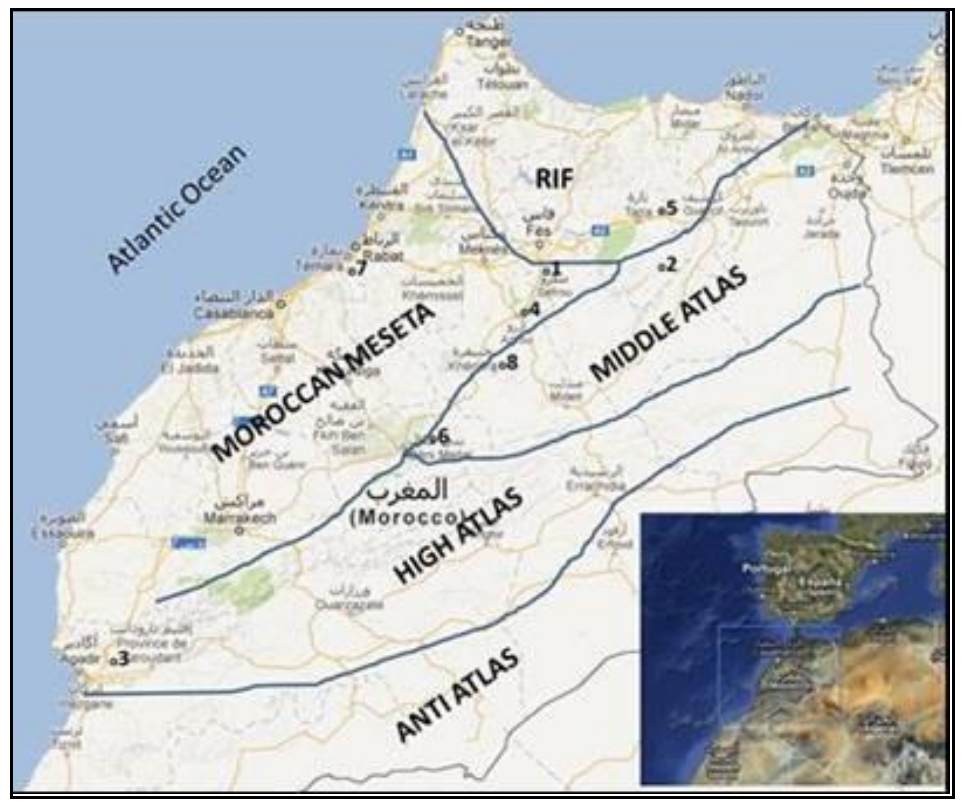

Figure 1. Main tectonic units of Morocco (Modified from Crevello, 1991 and Ledo et al., 2011). 
The location of the studied samples (1 to 8$)$ are also shown in accordance with Table 1.

\section{RESULT AND DISCUSSION}

Specific name (or local name), location and color of the collected samples representing carbonate marbles and basalt stones were displayed in Table 1 . The investigated rock types are also shown in Figure 2 and 3. The mineralogical composition, cement characteristics and rock ty pe were also indicated in Table 1. It can be said that the carbonate samples (limestone and dolomite) have micritic and sparitic cement. At most samples (except sample 4 and 5), these two agents found together. Crystalline limestone (marble) of Timahdite (sample 4) and dolomitic limestone of Taza (sample 5) have a cement of sparite. Basalt sample of Khenifra (sample 8) has a volcanic origin and has a glassy matrix. The Khenifra basalt and Volubilis dolomitic limestones have quite large pores (Figure 4 and 5), but limestones of Bir Jdid have more connected pores than all other samples since it has the highest e ffective porosity.

Carbonate samples overwhelmingly made of calcite and dolomite minerals with notable amount of organic matter, iron oxides and extraclasts in some samples, for example sample 4 and sample 5 (Table 1). The glauconite minerals were observed in two samples (sample 1 and sample 4) as intraclasts. On the other hand, dolomitic limestone of Volubilis (sample 2) has plenty of pizoids, while some samples have fossils and stilolites (sample 4 and 7). It is notable that one sample (sample 1) have green algae. The sole, non-carbonaceous sample (sample 8 ) of this study has mostly pyroxene and plagioclase minerals as well as some olivine and opaque minerals in composition. The XRD examinations also revealed most of these observations. Some of the olivine minerals in this sample were iddingsitised (altered olivine consisting of a mixture of clay minerals, iron oxides and ferrihydrites).

The bulk-dry density, effective porosity, dry weight loss (DWL) and loss on ignition (LOI) values of the studied samples were show $n$ in Table 2. The bulk-dry densities of the samples are between $2.23 \mathrm{~g} / \mathrm{cm}^{3}$ and $2.71 \mathrm{~g} / \mathrm{cm}^{3}$. Effective porosity values of three samples are very close to zero (sample 3,4 and 7 ). The limestone of Bir Jdid (sample 1 ) has the highest $(10.81 \%$ ) effective porosity, indicating more connected pores. In addition, this sample has the highest $(4.61 \%)$ DWL value. The dolomitic limestones of Taza (Sample 5) and basalt of Khenifra (sample 8) have considerably higher effective porosity values which are $5.25 \%$ and $6.67 \%$ respectively. The highest dry weight loss value belongs to the sample 1 (4.61\%) which represent the limestone of Bir Jdid. The sample 5 has also high DWL while three samples (sample 3,6 and 7) have DWL value of zero. The Khenifra basalt has the low est LOI value with $1.26 \%$. The LOI values are relatively uniform (except sample 3 which has $34 \%$ LOI) for other samples. 
Table 1. Specific name, location, color and some mineralogical features of the Moroccan carbonate marbles and basalt stone.

\begin{tabular}{|c|c|c|c|c|c|}
\hline $\begin{array}{l}\text { Sample no- specific } \\
\text { name- location }\end{array}$ & Rock type & Color & Cement & Minerals & Remarks \\
\hline 1-Bir Jdid-Sefrou & Limestone & $\begin{array}{l}\text { Pale } \\
\text { brown }\end{array}$ & $\begin{array}{l}\text { Mainly sparite } \\
\text { with less micrite }\end{array}$ & $\begin{array}{l}\text { \%92 } \\
\text { calcite, } \\
\% 8 \text { dolomite }\end{array}$ & $\begin{array}{l}\text { Opaque } \\
\text { minerals and glauconite } \\
\text { present, remains of } \\
\text { green algae and fossils } \\
\text { are observed as } \\
\text { extraclasts }\end{array}$ \\
\hline $\begin{array}{l}\text { 2-Volubilis- } \\
\text { Taghazout }\end{array}$ & $\begin{array}{l}\text { Dolomitic } \\
\text { limestone }\end{array}$ & Beige & $\begin{array}{l}\text { Micrite- } \\
\text { dolomicrite Sparite- } \\
\text { dolosparite }\end{array}$ & $\begin{array}{l}\% 60 \text { calcite, } \\
\% 40 \text { dolomite }\end{array}$ & $\begin{array}{l}\text { Plenty of } \\
\text { pizoids }\end{array}$ \\
\hline 3- Rose-Agadır & $\begin{array}{l}\text { Crystalline } \\
\text { limestone } \\
\text { (marble) }\end{array}$ & Pinkish & $\begin{array}{l}\text { Sparite with } \\
\text { quarts and feldspar as } \\
\text { extraclasts }\end{array}$ & $\begin{array}{l}\% 94 \text { calcite, } \\
\% 6 \text { extraclasts }\end{array}$ & \\
\hline 4- Timahdite- Ifrane & $\begin{array}{l}\text { Crystalline } \\
\text { limestone } \\
\text { (marble) }\end{array}$ & Pink & Sparite & $\begin{array}{l}\% 90 \text { sparite, } \\
\% 8 \text { organic matter } \\
\text { and/or iron oxide, } \\
\% 2 \text { extraclasts } \\
\text { (mainly glauconite) }\end{array}$ & $\begin{array}{l}\text { Fossils and } \\
\text { stylolites are present }\end{array}$ \\
\hline 5- Taza-Taza & $\begin{array}{l}\text { Dolomitic } \\
\text { limestone } \\
\text { (very porous) }\end{array}$ & Beige & Sparite & $\begin{array}{l}\% 84 \text { sparite, } \\
\% 13 \text { dolomite, } \\
\% 3 \text { extraclasts }\end{array}$ & $\begin{array}{l}\text { Very porous, } \\
\text { idiomorphic and } \\
\text { hypidiomorphic } \\
\text { dolomite rhombe ders } \\
\text { are visible }\end{array}$ \\
\hline 6- Bejaad-Smaala & $\begin{array}{l}\text { Dolomitic } \\
\text { limestone }\end{array}$ & $\begin{array}{l}\text { Beige- } \\
\text { yellow }\end{array}$ & $\begin{array}{l}\text { Micrite, } \\
\text { sparrycalcite, dolomite, } \\
\text { dolosparite }\end{array}$ & $\begin{array}{l}\% 55 \text { calcite, } \\
\% 45 \text { dolomite }\end{array}$ & $\begin{array}{l}\text { Fossils, } \\
\text { peloidalmicrite and } \\
\text { idiomorphic } \\
\text { dolomite rhombeders } \\
\text { are pre sent }\end{array}$ \\
\hline $\begin{array}{l}\text { 7- Gris-Oued } \\
\text { Cherrat }\end{array}$ & $\begin{array}{l}\text { Dolomitic } \\
\text { limestone }\end{array}$ & Grey & $\begin{array}{l}\text { Micrite, sparite, } \\
\text { dolomicrite, dolos parite }\end{array}$ & $\begin{array}{l}\% 85 \text { calcite, } \\
\% 15 \text { dolomite }\end{array}$ & $\begin{array}{l}\text { Stilolite and } \\
\text { fossils are present }\end{array}$ \\
\hline $\begin{array}{l}\text { 8- Black Khenifra- } \\
\text { Meknes }\end{array}$ & Basalt & Black & $\begin{array}{l}\text { Intersertal- } \\
\text { phylotacsitic texture }\end{array}$ & $\begin{array}{l}\% 30 \text { plagioclase, } \\
\% 35 \text { pyroxene, } \\
\% 27 \text { matrix } \\
\% 3 \text { altered matter, } \\
\% 5 \text { olivine and } \\
\text { opaque minerals }\end{array}$ & $\begin{array}{l}\text { Some of olivines are } \\
\text { iddingsitised }\end{array}$ \\
\hline
\end{tabular}




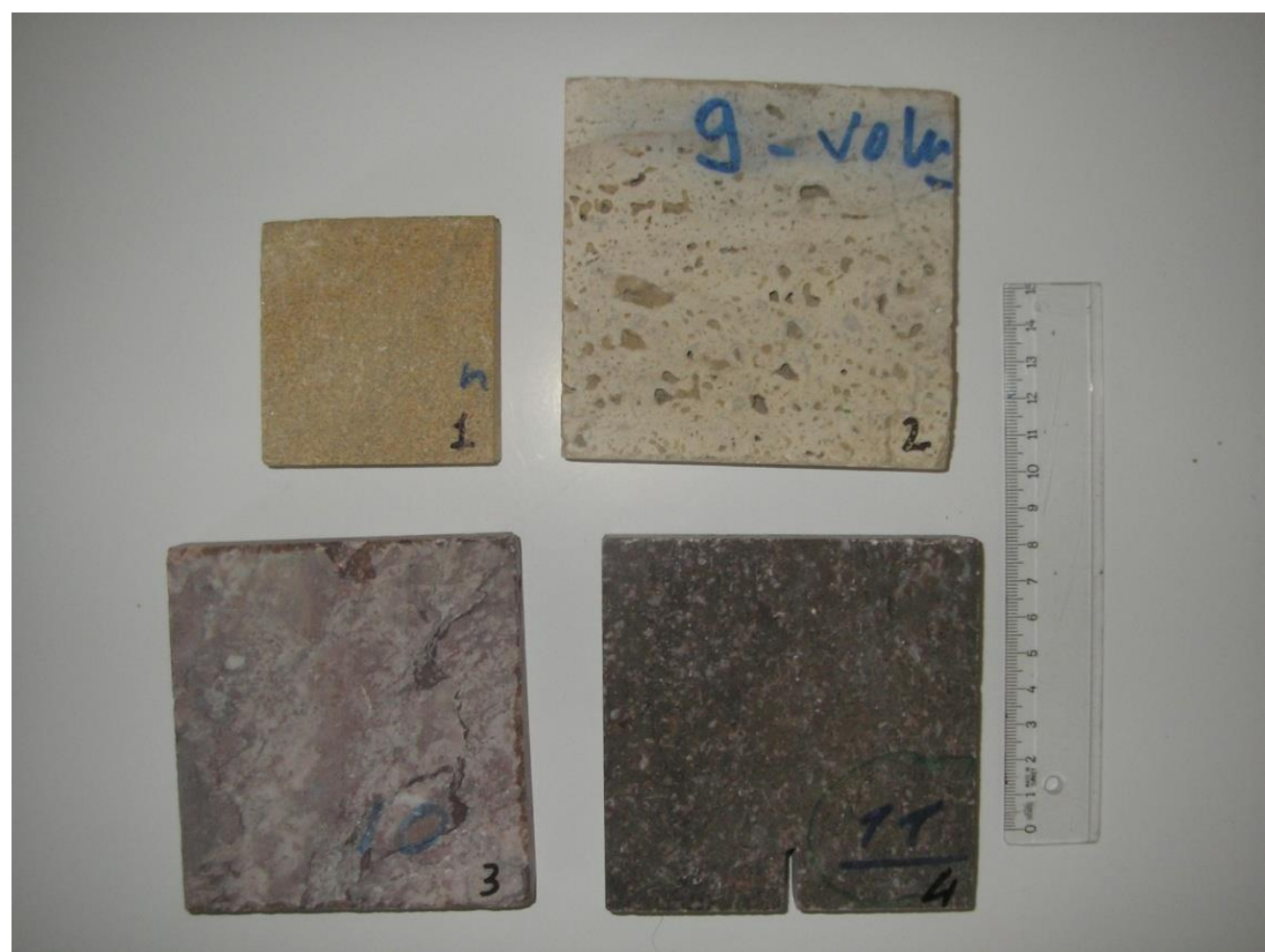

Figure 2. The studied samples of Bir Jdid limestone (1), Volubilis dolomitic limestone (2), Rose marble (Ifrane) (3) and Timahdite marble (4).

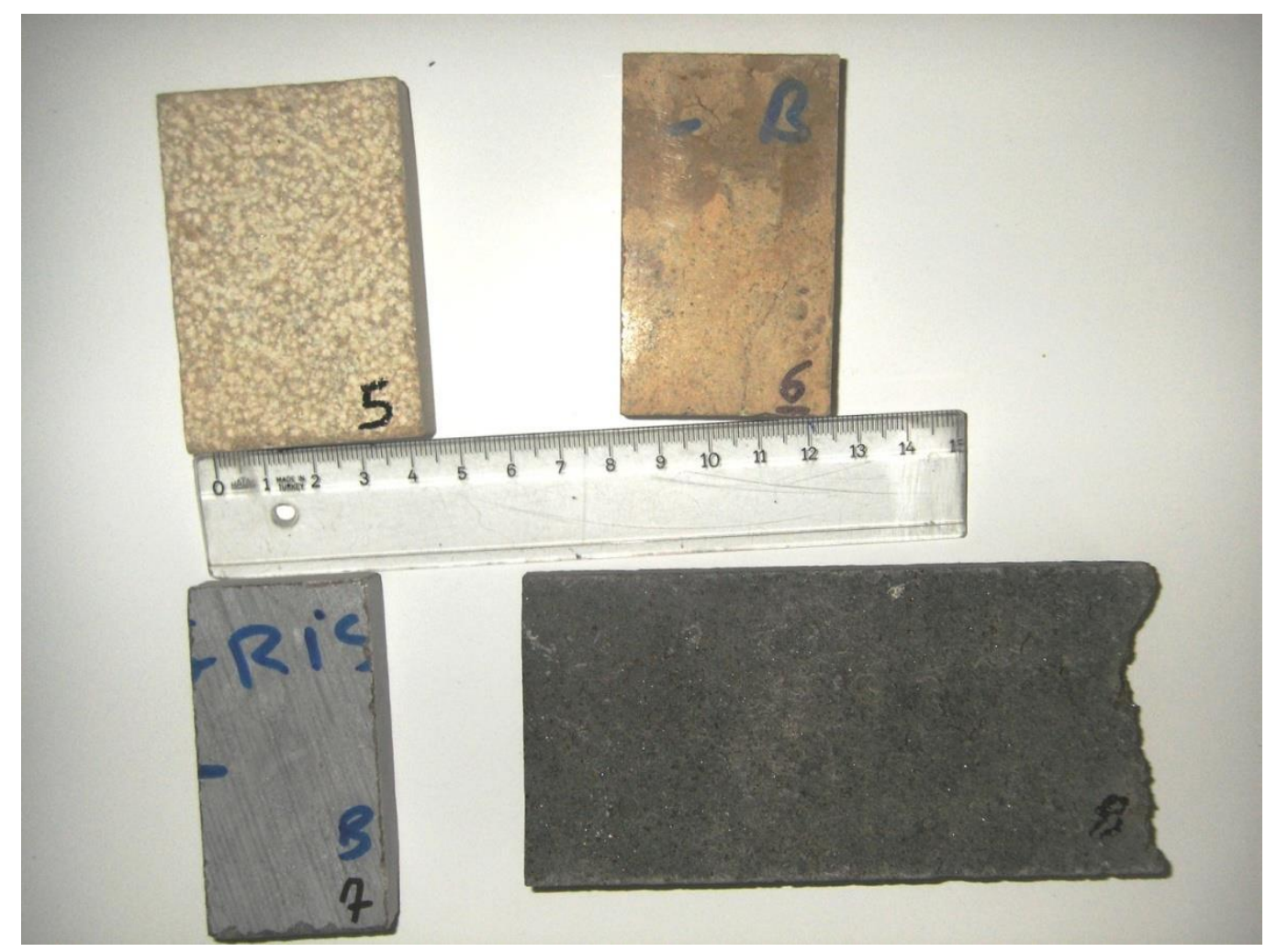

Figure 3. The studied samples of dolomitic limestones of Taza (5), Bejaad (6), and Gris (7), and Khenifra basalt (8). 


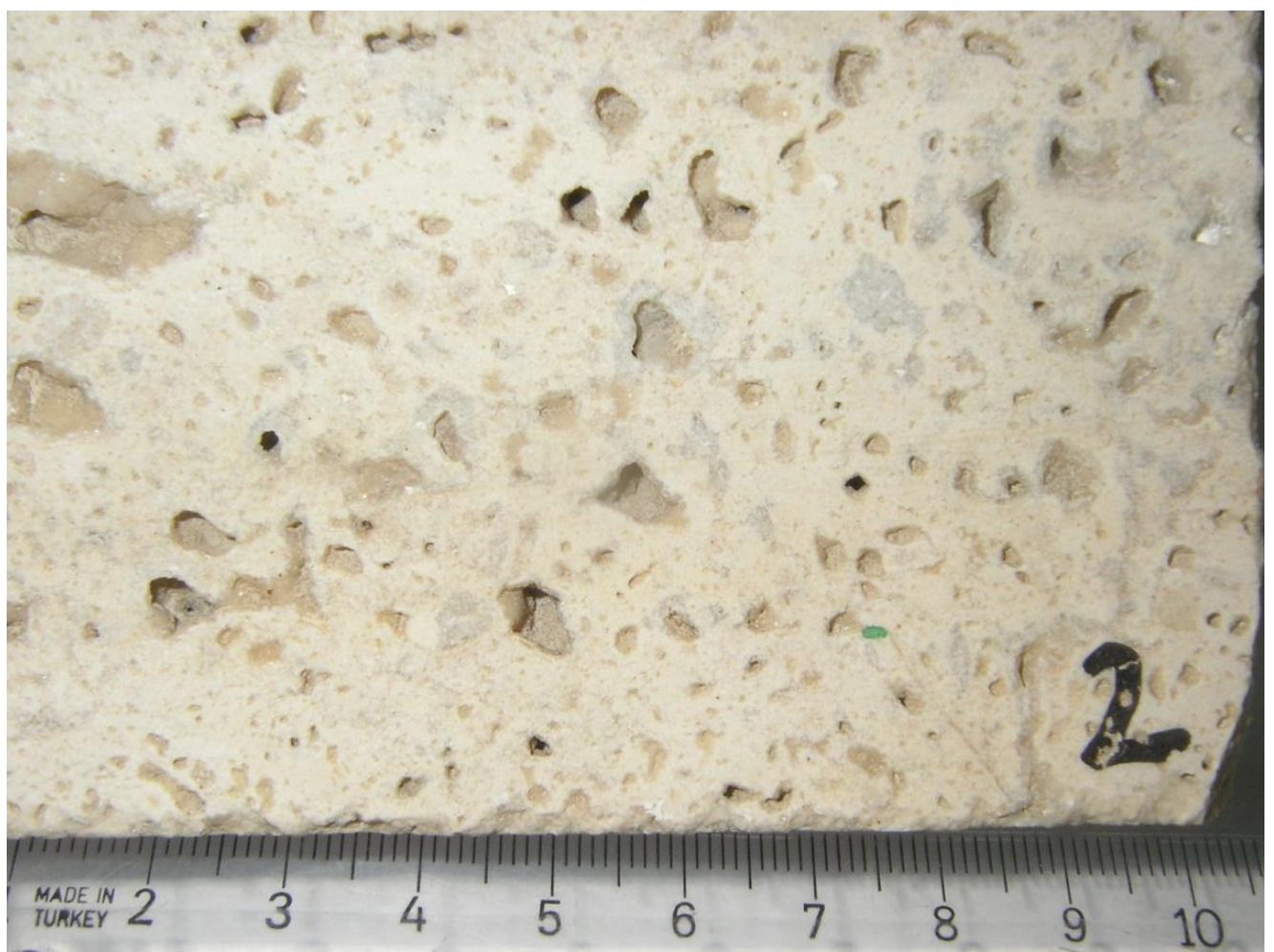

Figure 4. The studied sample of the Volubilis dolomotic limestone. Note that quiet large (up to $5 \mathrm{~mm}$ ) pores.

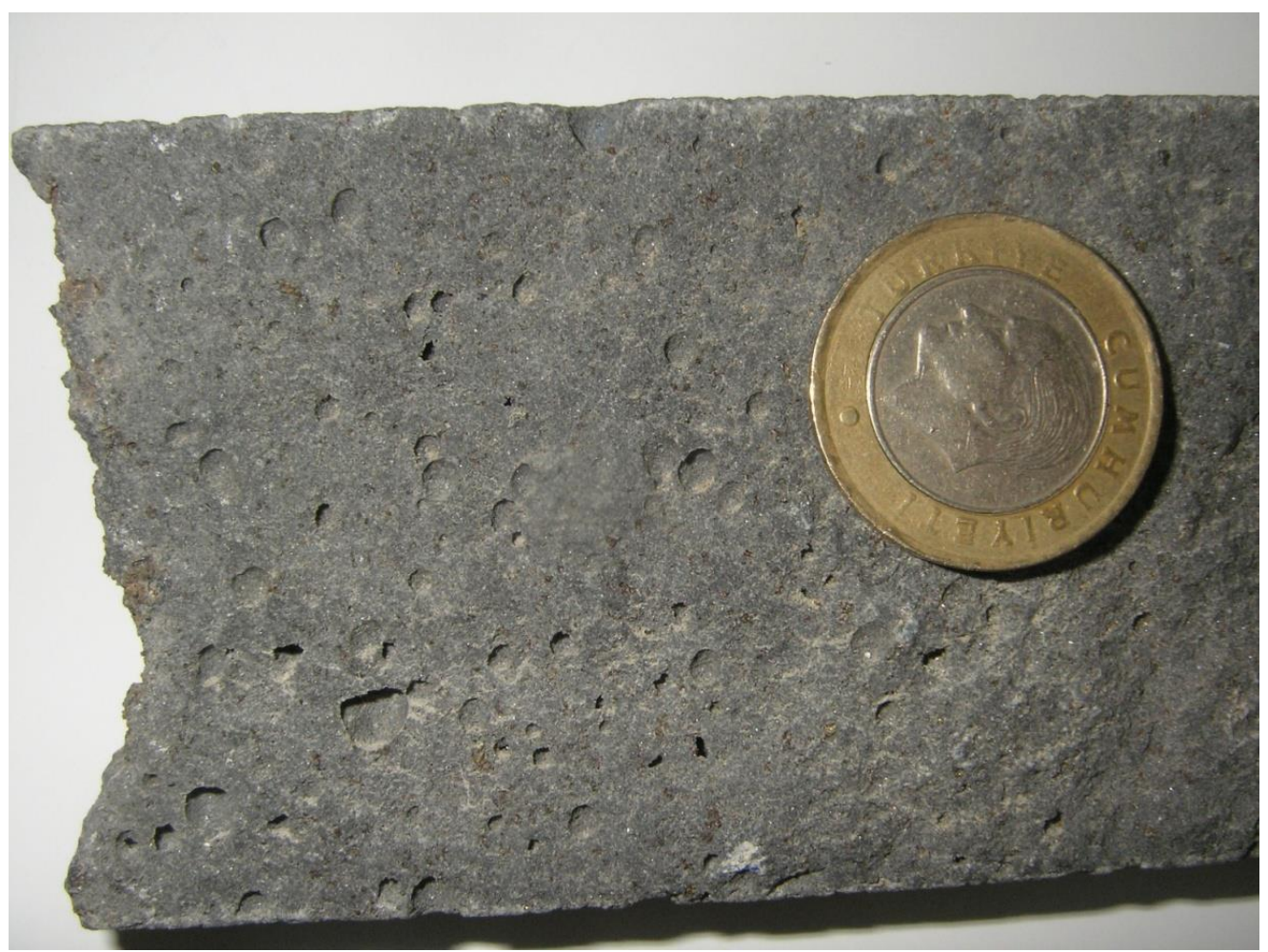

Figure 5. The studied sample of Khenifra basalt. The pores relatively more connected than all other samples (except Bir Jdid limestone).

It is clear from the Table 2 that there has been no positive or negative correlation between the bulk-dry densities and powder densities. When excluding sample 8 , a slight positive correlation can be seen 
between the effective porosities and dry weight loss values of the samples. This is especially true for sample 1 and sample 5. These two samples also have relatively high powder densities. As indicated earlier, the sole non-carbonaceous sample of this study (Khenifra basalt) has a very distinctive effective porosity $(6.67 \%)$, dry weight loss $(0.99 \%)$ and loss on ignition $(1.26 \%)$ values. Note that this sam ple is also quite different mineralogical composition. This indicates that the effect of salt (in this study $\mathrm{Na}_{2} \mathrm{SO}_{4}$ ) on rocks controlled not only by porosity, density and environmental conditions but mineralogical composition is also vital.

Table 2. Density, porosity, dry weight loss and loss on ignition values of the studied carbonate marble and basalt samples.

\begin{tabular}{|c|cccc|}
\hline Sample number & $\begin{array}{c}\text { Bulk-dry } \\
\text { density (g/cm } \mathbf{3})\end{array}$ & $\begin{array}{c}\text { Effective } \\
\text { porosity (\%) }\end{array}$ & $\begin{array}{c}\text { Dry weight loss } \\
\mathbf{( \% )}\end{array}$ & $\begin{array}{c}\text { Loss on ignition } \\
\left(\mathbf{\%}, \mathbf{1 0 0 0}^{\circ} \mathbf{C}\right)\end{array}$ \\
\hline $\mathbf{1}$ & 2.23 & 10.81 & 4.61 & 41.88 \\
$\mathbf{2}$ & 2.44 & 2.36 & 0.78 & 44.00 \\
$\mathbf{3}$ & 2.72 & 0.18 & 0 & 34.00 \\
$\mathbf{4}$ & 2.72 & 0.06 & 0.56 & 40.35 \\
$\mathbf{5}$ & 2.51 & 5.25 & 3.01 & 43.36 \\
$\mathbf{6}$ & 2.62 & 2.92 & 0 & 44.99 \\
$\mathbf{7}$ & 2.71 & 0 & 0 & 43.19 \\
$\mathbf{8}$ & 2.58 & 6.67 & 0.99 & 1.26 \\
\hline
\end{tabular}

\section{CONCLUSIONS}

The following conclusions can be inferred from this study:

(I) This study is a first approach to understand some geological and geomechanical properties of Moroccan carbonate marbles and basalt stone which are widely used in Morocco.

(II) The studied carbonate marbles and basalt stone have a relatively uniform bulk-dry density values while their effective porosity and dry weight loss values are variable.

(III) The carbonate rocks are mostly made of calcite and dolomite minerals with micritic and sparitic cement. Some rocks also have considerable amount of extraclasts and organic matter as well as fossils.

(IV) The sole, non-carbonaceous sample of Khenifra basalt has very different mineralogical composition than the others. These differences gave rise the different dry weight loss and loss on ignition values of this sample, since it clearly has higher silica and different chemical composition.

(V) Bir Jdid limestone and Taza dolomitic limestone are the most sensitive rocks against salt $\left(\mathrm{Na}_{2} \mathrm{SO}_{4}\right)$ decay, therefore the outdoor use of these rocks should be avoided.

\section{ACKNOWLEDGEMENTS}

Our thanks go to Dr. M. Salim Öncel for taking XRD graphs and their identification. The marble and stone company of Soreil Marbre Sarl (Rouye de Rabat, Km 5, Tanger, Morocco) provided samples. V. Zedef, A. Döyen and A. R. Söğüt financially supported by the Council of Higher Education (Yüksek Öğretim Kurumu-YÖK) of Turkey during three months visit to Morocco in 2012. The two anonymous referees were also gratefully thanked for their valuable review. 


\section{REFERENCES}

Blows, J. F., Carey, P.J., Poole, A. B., 2003, "Preliminary Investigations into Caen Stone in The UK; Its Use, Weathering and Comparison with Repair Stone" Building and Environment, Vol. 38, pp.1143 - 1149 .

Crevello, P. D., 1991, “High-frequency Carbonate Cycles and Stacking Patterns: Interplay of Orbital Forcing and Subsidence on Lower Jurassic Rift Platforms, High Atlas, Morocco" In Sedimentary Modeling: Computer Simulations and Methods for Improved Parameter Definition (ed. E. V. Franseen, W. L. Watney, C. G. St C. Kendall \& W. Ross). Kansas Geological Survey Bulletin no. 233, pp.207-230.

Eden, M. A., 1990, The In-Service Performance of Limestone Building Stones and Their Predominant Mechanisms of Decay, Unpublished M.Sc. dissertation, Queen Mary and West-End College, University of London.

Lal Gauri, K., Bandyopadhyay, J. K., 1999, Carbonate Stone: Chemical Behavior, Durability and Conservation", New York: Wiley.

Ledo, J., Jones, A. G., Siniscalchi, A., Campanya, J., Kıyan, D., Romano, G., Rouai, M., 2011, “Electrical Signature of Modern and Ancient Tectonic Processes in The Crust of The Atlas Mountains of Morocco", Physics of the Earth and Planetary Interiors, Vol. 185, 3-4, pp.82-88.

Papida, S., Murphy, W., May, E., 2000, “Enhancement of Physical Weathering of Building Stones by Microbial Populations", International Biodeterioration \& Biodegradation, Vol. 46, 4, pp.305317.

Schaffer, R.J., 1932, “The Weathering of Natural Building Stones” DSIR, Building Research Special Report, 18, Stationary Office, London. 34 p.

Stets, J., Wurster, P., 1982, “Atlas and Atlantic-Structural Relations” in, Geology of the Northwest Africa Continental Margin, von Rad, U., Hinz, K, Samtheir, M., and Seibold, E., eds.: SpringerVerlag, New York, pp.69-85.

Winkler, E. M., 1966, “Important Agents of Weathering for Building and Monumental Stone" Engineering Geology, Vol .1, pp.381-400.

Yu, S., Oguchi, C. T., 2010, “Role of Pore Size Distribution in Salt Uptake, Damage, and Predicting Salt Susceptibility of Eight Types of Japanese Building Stones", Engineering Geology, Vol. 115, pp. 226-236.

Zedef, V., Koçak, K., Döyen, A., Özşen, H., Kekeç, B., 2007, “Effect of Salt Crystallization on Stones of Historical Buildings and Monuments, Konya, Central Turkey", Building and Environment, Vol. 42, pp. 1453-1457. 